\title{
Adrenal Gland Capsule
}

National Cancer Institute

\section{Source}

National Cancer Institute. Adrenal Gland Capsule. NCI Thesaurus. Code C32050.

The thin fibrous tissue that surrounds the adrenal gland. 